DOI $10.14746 / \mathrm{ssp} .2015 .1 .11$

Sylwia GÓRZNA

Akademia Pomorska, Słupsk

\title{
Polityczny oddźwięk Deklaracji o stosunku Kościoła do religii niechrześcijańskich Nostra aetate ${ }^{1}$
}

\begin{abstract}
„Promulgowanie deklaracji soborowej O stosunku Kościoła do religii niechrześcijańskich jest wkładem całej ludzkości w sprawę pokoju, jest obiecującym początkiem długiej i zobowiązującej drogi zmierzającej do osiagnięcia trudnego celu całej ludzkości, gdzie wszyscy ludzie będą czuć się i postępować jak dzieci tego samego Ojca, który jest w niebiosach”.
\end{abstract}

(Czajkowski, 1966, s. 132)

Streszczenie: Otwarcie Kościoła katolickiego na dialog z innymi religiami ma swoje źródło w Soborze Watykańskim II (1962-1965), który w wielu dokumentach wyraził pozytywny stosunek Kościoła katolickiego do religii niechrześcijańskich. Był wydarzeniem szczególnym i przełomowym w dziejach Kościoła katolickiego. Autorka przedstawiła dokument soborowy, który proponuje, aby wierni Kościoła nawiązali dialog z wyznawcami różnych religii, aby szanowali wartości obecne w tych religiach.

Deklaracja o stosunku Kościoła do religii niechrześcijańskich Nostra aetate rozpoczęła proces reorientacji Kościoła wobec wyznawców różnych religii m.in. islamu i judaizmu, której podstawą jest wiara w jednego Boga (monoteizm). Należy zwrócić uwagę zwłaszcza na numer 3. tej deklaracji, który podkreśla, iż Kościół katolicki z szacunkiem odnosi się do wyznawców islamu oraz numer 4., który zawiera sformułowanie zdejmujące z Żydów odpowiedzialność za Bogobójstwo, porusza bolesną sprawę antysemityzmu, jednak nie z pobudek politycznych. Dzięki Deklaracji wielu katolików zmieniło podejście do wyznawców innych religii.

Ten dokument jest świadectwem potwierdzającym szczególną troskę Kościoła o nawiązanie przyjaznych relacji z wyznawcami różnych religii m.in. islamu i judaizmu. Autorka jest przekonana, iż dokument przyczynia się do pokojowego współistnienia religii, które powinny podjać służbę na rzecz pokoju między narodami, co stanowi o jego politycznym wymiarze.

Słowa kluczowe: Sobór Watykański II, Deklaracja o stosunku Kościoła do religii niechrześcijańskich Nostra aetate, dialog międzyreligijny, islam, judaizm

1 Fragmenty artykułu wykorzystano w pracy Górzna, 2013, s. 36-40. 
Sobór Watykański II (1962-1965 - SWD) przyznał, iż w ciagu wieków istniała wrogość ze strony katolików, muzułmanów i Żydów i wezwał do braterskiego dialogu. Ludzie, którzy wierzą w tego samego Boga nie są potępieni, ale pozostają dziećmi jednego Boga (Latourelle, 1999, s. 156).

28.10.1965 r., podczas czwartej sesji SWD, uchwalono Deklarację o stosunku Kościoła do religii niechrześcijańskich Nostra aetate (łac. $W$ naszej epoce) (DRN) (Sherwin, Kasimow, 2001, s. 152). Dopiero 8.10.1966 r. została opublikowana przez papieża Pawła VI (pontyfikat w latach 1963-1978) w oficjalnym dzienniku urzędowym papieskim Acta Apostolicae Sedis (AAS) (Mysłek, Nowaczyk, 1985, s. 203-204). Nie nadano jej mocy soborowego dekretu, ale stała się jedynie oświadczeniem, stanowiąc rodzaj dyrektywy, którą członkowie Kościoła katolickiego powinni się kierować w stosunku do wyznawców innych religii. Należy podkreślić, iż ma ona jednak znaczenie wyjątkowe, ponieważ po raz pierwszy w swych dziejach Kościół sformułował w niej swoje stanowisko wobec religii niechrześcijańskich (Ibidem, s. 204).

$\mathrm{Z}$ powstaniem tego dokumentu wiąże się złożony proces obrad, a społeczność żydowska odegrała znaczącą rolę w tych skomplikowanych obradach, jak również w ukształtowaniu dokumentu traktującego o Żydach (Chrostowski, 1992, s. 42).

Sprawa problematyki innych religii znalazła się w porządku obrad SWD przypadkowo. Francuski rabin Jules Isaac (1877-1963) zasugerował papieżowi Janowi XXIII (pontyfikat 1958-1963), iż Kościół katolicki powinien w najbliższym czasie wydać oficjalną deklarację przeciwdziałającą nauczaniu pogardy w odniesieniu do Żydów. Sugestię przyjęto, a przygotowanie tekstu powierzono Augustynowi kard. Bea (1881-1968), przewodniczącemu Sekretariatu ds. Jedności Chrześcijan. Ze względu na sprzeciw wobec tej inicjatywy, głównie ze strony biskupów Bliskiego Wschodu i sugestie biskupów Afryki i Azji, doszło do poszerzenia tekstu nie tylko do Żydów, ale także do wyznawców innych religii (Fitzgerald, 2005, s. 34).

W 1960 r. Jan XXIII i Isaac, a następnie Paweł VI i Abraham Joshua Heschel (1907-1972, pionier dialogu żydowsko-chrześcijańskiego) prowadzili rozmowy, które doprowadziły do przyjęcia przez SWD deklaracji $D R N$ nr 4 (Krajewski, 2007, s. 51). Heschel miał odegrać znaczącą rolę w artykułowaniu żydowskiego punktu widzenia wobec twórców $D R N$. W przełomowych momentach obrad odwiedzał Rzym i bronił spraw narodu żydowskiego. Przypisuje się mu zasługę zmiany sposobu myślenia wielu Ojców Soboru i doprowadzenia do ostatecznego podjęcia decyzji (Chrostowski, 1992, s. 43). 
W kształtowaniu tego dokumentu ${ }^{2}$, społeczności żydowskiej, udało się w sposób bezprecedensowy mieć pewien udział, który symbolizowały życzenia i przesłanie, wystosowane przez Głównego Rabina Rzymu Elio Toaffa (ur. 1915 r.). To był pierwszy przypadek przekazania przez przywódcę żydowskiego pozdrowień Soborowi (Chrostowski, 1992, s. 43).

Żydowskie zaangażowanie w SWD miało też konsekwencje negatywne, bowiem pod koniec pierwszej sesji, wśród Ojców (zob. Ignatowski, 2007) Soborowych rozprowadzono szereg ulotek o prymitywnie antysemickiej wymowie. Z dzisiejszej perspektywy można uznać, iż ulotki te były bardziej wymierzone w soborowych liberałów niż w Żydów (Ibidem, s. 45).

Przy ocenie czynników kształtujących $D R N$, najbardziej znaczący mógł być element całkowicie nie pasujący do kontekstu teologicznych debat, a mianowicie geopolityka Bliskiego Wschodu. Świat żydowski nie posiadał przedstawicieli akredytowanych na obradach, zaś przedstawiciele państw arabskich, posiadający stosunki dyplomatyczne z Watykanem, byli obecni jako goście oficjalni (Ibidem, s. 49). Kluczową sprawę stanowiła przyczyna zainteresowania świata arabskiego dokumentem Kościoła katolickiego w kwestii żydowskiej, któremu nie sposób przypisać złej woli czy nienawiści do Żydów ze strony wrogów państwa Izrael. Było ono powodowane dokładnym przeciwieństwem politycznego wymiaru trosk, jakim kierowała się żydowska społeczność (Chrostowski, 1992, s. 50-51). Świat arabski działał w oparciu o założenie konieczności zachowania zarzutu Bogobójstwa, aby utrzymać katolickie uzasadnienie sprzeciwu wobec ojczyzny żydowskiej, zaś Żydzi działali w kierunku przeciwnym, co wynikało z poczucia, iż usunięcie zarzutu Bogobójstwa mogłoby doprowadzić m.in. do zniesienia konieczności sprzeciwiania się przez Kościół prawomocności żydowskich aspiracji politycznych. Zaangażowanie obu stron wynikało ze względów, które można określić mianem ,politycznych" (Ibidem, s. 51).

W genezie tekstu $D R N$ (zob. Wawrzyńska-Furman, 2007, s. 140-143) krzyżowały się inicjatywy świata żydowskiego i papieży Jana XXIII, a następnie Pawła VI, którym przyświecały dwie podstawowe intencje: pierwsza natury politycznej dotycząca potępienia antysemityzmu ${ }^{3}$, druga o charakterze teologicznym, która domagała się wypowiedzi Kościoła ka-

2 Treść tego dokumentu zob. Groblicki, Florkowski, 1986, s. 334-338.

3 Bortkiewicz dodaje, iż antysemityzm to postawa rasistowska, a u jej podstaw leży przekonanie o niższości rasy żydowskiej albo dążenie do eliminowania Żydów z racji politycznych (Bortkiewicz i in., 1999, s. 73). 
tolickiego dotyczącej jego izraelskich korzeni, które nie powinny być nigdy przez niego zapomniane (Groblicki, Florkowski, 1986, s. 328).

Ostateczny tekst deklaracji opiera się na II rozdziale konstytucji De Ecclesia, w którym przeanalizowano związki łączące katolików z niechrześcijanami z teologicznego punktu widzenia (Wnuk, 1966, s. 14). $D R N$ nie tylko określiła na nowo stosunek Kościoła katolickiego do religii niechrześcijańskich, ale również podkreśliła wyjątkową więź łączącą judaizm z katolicyzmem, który odróżnia go od związków istniejących między Kościołem katolickim i jakąkolwiek religią niechrześcijańską (Sherwin, Kasimow, 2001, s. 152). Dzięki DRN doszło do wizyty papieża Jana Pawła II (pontyfikat w latach 1978-2005) w synagodze w 1986 r. i pielgrzymki do Izraela w 2000 roku (Krajewski, 2007, s. 85).

$D R N$ (zob. Turowicz, 1990, s. 18-19) obwieszcza, iż „Duch pojawia się tam, gdzie chce, a promienie Prawdy", które powinny oświecać wszystkich ludzi, można znaleźć również w innych religiach. Jest to kres zasady: „Poza Kościołem nie ma zbawienia" (Larebiere, 1999, s. 73). Przyznanie, że także inne religie mogą prowadzić do zbawienia, było gruntownym aktem dla Kościoła katolickiego (Zizola, 2000, s. 9). W każdej tradycji religijnej jest obecna boska Rzeczywistość, jedna wieczna Prawda (Griffiths, 1985, s. 56).

Pięć punktów tego dokumentu ujmuje katolicką doktrynę o stosunku Kościoła katolickiego do religii niechrześcijańskich. Zadaniem chrześcijanina, według SWD, jest poszukiwanie wartości ogólnoludzkich we wszystkich religiach (Sakowicz, 1988, s. 39). Kościół uznał konieczność oficjalnego oraz publicznego potwierdzenia wszystkich przedsięwzięć, zmierzających do coraz głębszego poznania duchowego i kulturowego bogactwa innych religii oraz przyczyniających się do wzajemnego poszanowania i wspólnej troski o pokój (Wolanin, 1993, s. 13).

Papież Jan Paweł II bardzo często przypominał i objaśniał jej treść, nawiązując do niej wprost lub pośrednio (Chrostowski, 2005, s. 27). Papieskie posługiwanie na Stolicy św. przypadło w okresie posoborowym, kiedy inspiracja $D R N$ przyoblekała się w konkretne kształty (Jan Paweł II, 1994, s. 87). Celem tej deklaracji nie jest podanie wykładu o religiach czy o różnicach pomiędzy nimi a katolicyzmem, ale podkreślenie więzi, która istnieje pomiędzy ludźmi a religiami, stanowiącej podstawę współpracy oraz dialogu (Pawłowicz, 1986, s. 82). Ma cel pokojowy, łączy się z innymi dekretami np. z Dekretem o ekumenizmie Unitatis redintegratio ${ }^{4}$

4 Treść dekretu zob. Groblicki, Florkowski, 1986, s. 203-218. 
z 1964 r. i Dekretem o działalności misyjnej Kościoła Ad gentes divinitus ${ }^{5}$ z 1965 roku (Bogacki, Moys, 1986, s. 427). Należy czytać ją łącznie z innymi dokumentami SWD, ponieważ stwarzają one odpowiednie ramy dla zagadnień stosunku Kościoła katolickiego do religii niechrześcijańskich (Groblicki, Florkowski, 1986, s. 331). Została poświęcona zwięzłemu podkreśleniu zawartych w tych religiach wartości i dóbr (Wojtyła, 1972, s. 25).

Eugeniusz Sakowicz ${ }^{6}$ wskazuje na zawarte w niej stwierdzenia, które mają istotny wpływ na rozwój pojęcia dialog. Pierwszym z nich jest prawda o Bogu, który jest Ojcem wszystkich ludzi, który akceptuje każdego człowieka. Drugim jest stwierdzenie, iż wszyscy ludzie są braćmi, co wynika z miłości Boga do nich. Kolejne odnosi się wprost do postawy Kościoła wobec innych religii, wyrażające akceptację i uznanie elementów prawdy obecnych w niechrześcijańskich tradycjach religijnych, a co za tym idzie szacunek dla ich wyznawców (Sakowicz, 2000, s. 62-63).

Na pierwszym miejscu $D R N$ mówi o religiach tzw. ludów pierwotnych, które mieszkają w nielicznych szczepach w Afryce, Azji, Australii, na Alasce i Ziemi Ognistej (Pawłowicz, 1986, s. 83).

W nr 1. Deklaracji czytamy: „W swym zadaniu popierania jedności i miłości wśród ludzi, a nawet wśród narodów, główną uwagę poświęca [Kościół - dodała S.G.] temu, co jest ludziom wspólne i co prowadzi do dzielenia wspólnego losu".

$\mathrm{W}$ nr 2. nie zajmuje się wszystkimi religiami Azji, ale poświęca po kilka zdań dwóm z nich: hinduizmowi i buddyzmowi (Ibidem, s. 85). Ojcowie Soboru stwierdzają m.in., iż także w hinduizmie istnieją rzeczy „prawdziwe i święte” (Imbach, 1985, s. 34). Kościół wzywa swoich wyznawców, „aby z roztropnością i miłością przez rozmowy i współpracę z wyznawcami innych religii, dając świadectwo wiary i życia chrześcijańskiego, uznawali, chronili i wspierali owe dobra duchowe i moralne, a także wartości społeczno-kulturalne, które u tamtych się znajdują" (DRN, nr 2).

W nr 3. DRN stwierdza, iż Kościół katolicki z szacunkiem odnosi się do muzułmanów (Gioia, 1999, s. 85), (w oryginale muslimos, polski przekład niesłusznie mówi o mahometanach, ponieważ muzułmanie nie

5 Treść dekretu zob. ibidem, s. 436-474.

6 E. Sakowicz jest teologiem, religioznawca, konsultorem Rady do Spraw Dialogu Religijnego KEP, specjalistą w zakresie dialogu międzyreligijnego, zwłaszcza chrześcijańsko-muzułmańskiego. 
uważają się za mahometan - Mahomet jest dla nich prorokiem, nie Bogiem, ale za muslim, czyli poddanych Bogu) (Grabska, 1995, s. 11), którzy czczą jednego Boga, zaś Jezusa jako proroka (Mysłek, Nowaczyk, Nowaczyk, 1985, s. 205). Wskazuje, iż islam nawiązuje do Abrahama (Sakowicz, 2002, s. 143). Głównymi faktorami dialogu chrześcijańsko-muzułmańskiego jest wiara, kult jednego Boga oraz cześć oddawana Chrystusowi, uważanemu za proroka (zob. Górzna, 2008, z. 1, s. 57-66; Sakowicz, 1988, s. 39).

W pierwszej części nr 3. (zob. Michel, Fitzgerald, 1994, s. 3; Cassidy, 2005, s. 130-131) wymienia zasadnicze punkty islamskiego wyznania wiary i jej praktyki, zaś w drugiej podaje punkty oparcia dla dialogu: uleczenie ciagle istniejących ran, troska o wzajemne zrozumienie (Waldenfels, 1987, s. 52-53; Sakowicz, 1998, s. 48; Fitzgerald, 2005, s. 40), proponuje wyznawcom obu religii konkretne zadanie zaangażowania się we „wspólnej obronie i promocji sprawiedliwości społecznej, wartości moralnych, pokoju i wolności dla wszystkich ludzi" (Teissier, 1992, s. 170; Chat, 2005, s. 50). Deklaracja podkreśla znaczenie islamu, ponieważ zachowuje on w szczególny sposób pewne wartości religijne, odziedziczone częściowo od Żydów i chrześcijan (Bogacki, Moys, 1968, s. 443).

Należy podkreślić, iż Augustyn kard. Bea (Schmidt, 1992) utworzył w 1966 r. przy Sekretariacie do Spraw Jedności Chrześcijan, niezależne Biuro do Spraw Stosunków Katolicko-Żydowskich, którego zadaniem było koordynowanie prac, mających na celu zastosowanie w praktyce uchwał soborowych, wynikających z opublikowania $D R N \mathrm{nr} 4$ (Ignatowski, 1999, s. 83). Tenże numer podkreśla, iż obowiązkiem katolików jest uznawanie judaizmu za religię żywą, którą zastąpiło chrześcijaństwo. Należy rozpocząć braterski dialog i współpracę w przymierzu (Sherwin, 1995, s. 78-79). Wzywa do pojmowania chrześcijaństwa jako religii, która jest szczególnie bliska judaizmowi (Ibidem, s. 335).

Przypomina, iż początki wiary i wybrania Kościoła katolickiego znajdują się już u Patriarchów, Mojżesza oraz Proroków (Kowalski, 1994, s. 14), nie zapominając, iż od narodu żydowskiego otrzymał objawienie $S T$, że z niego wywodził się Chrystus według ciała oraz że również z tego ludu pochodzili apostołowie wielu pierwszych uczniów (Mysłek, Nowaczyk, 1985, s. 205).

Wskazując na duchowe dziedzictwo chrześcijan i Żydów SWD ,pragnie ożywić i zlecić obustronne poznanie się i poszanowanie, które osiągnąć można zwłaszcza [...] przez braterskie rozmowy" (DRN, $\mathrm{nr} 2)$. 
Opuszcza sformułowanie zdejmujące z narodu żydowskiego odpowiedzialność za Bogobójstwo (Deicidio) (Wnuk, 1966, s. 14). Tylko trzy grupy osób są w aspekcie historycznym odpowiedzialne za śmierć Jezusa: mała grupa żydowskich notabli (Rada Najwyższa), urzędnik zarządzający z ramienia Rzymu oraz garstka Syryjczyków należących do dziesiątego legionu stacjonującego w Palestynie. Oskarżanie Żydów o śmierć Boga jest więc błędem z teologicznego punktu widzenia (Konig, Kremer, 1992, s. 123). W numerze tym czytamy: „A choć władze żydowskie wraz ze swymi zwolennikami domagały się śmierci Chrystusa, jednakże to, co popełniono podczas Jego męki, nie może być przypisane ani wszystkim bez różnicy Żydom wówczas żyjącym, ani Żydom dzisiejszym. Chociaż Kościół jest nowym Ludem Bożym, nie należy przedstawiać Żydów jako odrzuconych ani jako przeklętych przez Boga, rzekomo na podstawie Pisma Świętego. Niechże więc wszyscy dbają o to, aby w katechezie i głoszeniu Słowa Bożego nie nauczali niczego, co nie licowałoby z prawdą ewangeliczną i z duchem Chrystusowym" (Bagrowicz, 2006, s. 13-14).

Ponadto dokument porusza bolesną kwestię antysemityzmu (Kowalski, 1994, s. 15; Bardecki, 1966, s. 254-256). W numerze tym czytamy: „Kościół, który potępia wszelkie prześladowania przeciw jakimkolwiek ludziom zwrócone, pomnąc na wspólne z Żydami dziedzictwo, opłakuje - nie z pobudek politycznych, ale pod wpływem religijnej miłości ewangelicznej - akty nienawiści, prześladowania, przejawy antysemityzmu, które kiedykolwiek i przez kogokolwiek kierowane były przeciw Żydom" (Weksler-Waszkinel, 2000, s. 318). Antysemityzm jest nie tylko ciężkim grzechem, ale jednocześnie ugodzeniem w sam rdzeń chrześcijaństwa. Postawa wrogości wobec wyznawców judaizmu to niewierność Przykazaniu miłości Boga i bliźniego, będącego pierwszym imperatywem danym chrześcijanom przez Trójjedynego Boga (Sakowicz, 2005, s. 58). Mimo, iż wydarzeniem bezpośrednim i zewnętrznym, skłaniającym Kościół do refleksji, był Holocaust, to na zmianę postawy Kościoła wobec Żydów i judaizmu nie wpłynęły wydarzenia polityczne (Jarmusiewicz, 2005, s. 155).

$\mathrm{Nr}$ 4. $D R N$ to serce całej deklaracji (Groblicki, Florkowski, 1986, s. 330), fundament gruntownej przebudowy myślenia i działania katolików (Chrostowski, 1998, s. 53). Ten numer jest podstawą, na której Jan Paweł II oparł swoje przemówienie w rzymskiej synagodze w 1986 roku (Sherwin, Kasimow, 1999, s. 131). „Zaowocował” dwoma niezależnymi dokumentami, zainspirowanymi jej treścią, opracowanymi przez Komisję Stolicy Apostolskiej do Spraw Stosunków Religijnych z Judaizmem: 
1) Wskazówki i sugestie w sprawie wprowadzenia w życie deklaracji soborowej Nosta aetate $n r 4$ (Chrostowski, Rubinkiewicz, 1990, s. 37-43) z 1974 r., 2) Żydzi i judaizm w głoszeniu Stowa Bożego i Katechezie Kościoła katolickiego. Wskazówki do właściwego przedstawiania tych zagadnień z 1985 r., które są „komentarzem”, a nawet rozwinięciem myśli, które są zawarte w „dokumencie - matce” (Sakowicz, 2000, s. 65).

$D R N$ w ostatnim numerze, 5. (Cassidy, 2005, s. 131) wzywa chrześcijan, aby podchodzili do wyznawców innych religii z gościnnością i pokora, nie zaś z poczuciem wyższości (Skowron-Nalbroczyk, Grodź, 2003, s. 186). Deklaracja podkreśla znaczenie braterstwa, miłości do drugiego człowieka, prawa do godności ludzkiej. „Nie możemy zwracać się do Boga jako do Ojca wszystkich, jeśli nie zgadzamy się traktować po bratersku kogoś z ludzi na obraz Boży stworzonych. Postawa człowieka wobec Boga Ojca i postawa człowieka wobec ludzi, braci, są do tego stopnia z sobą związane, że Pismo święte powiada: «Kto nie miłuje, nie zna Boga» (DRN, nr 5). SWD wzywa chrześcijan, aby „«dobrze postępując wśród narodów» [...] zachowywali pokój ze wszystkimi ludźmi, tak by prawdziwie byli synami Ojca, który jest w niebie" ( $D R N, \mathrm{nr} 5)$.

Nie ulega wątpliwości, iż $D R N$ doprowadziła do zmiany stanowiska Kościoła wobec islamu oraz wytyczyła drogę dialogu m.in. muzułmanów i katolików (Wąs, 2001, s. 88). Zainicjowała nie tylko dialog międzyreligijny (d.m.), ale również d.m. wewnątrz Kościoła katolickiego (Sakowicz, 2000, s. 64). Ta deklaracja wniosła wkład w zwalczanie antysemityzmu (Grinberg, 2001, s. 155). Jan Paweł II wielokrotnie podkreślał, iż antysemityzm jest ciężkim grzechem przeciwko Bogu i ludzkości (Oppenheim, 2000, s. 66).

Deklaracja ta zapoczątkowała proces gruntownej reorientacji Kościoła katolickiego wobec Żydów i judaizmu, oznaczała wejście w erę dialogu i braterskiej współpracy, zachowując jednocześnie pełen szacunek dla tożsamości obu stron (Pilarczyk, 1997, s. 123). Dzięki niej katolicy są zaangażowani w dialog z Żydami, który ma podstawy teologiczne i polega na teologicznej dyskusji między kompetentnymi teologami, reprezentującymi te dwie społeczności wierzących (Sherwin, 1995, s. 70).

Należy zgodzić się ze Stanisławem Krajewskim ${ }^{7}$, iż najważniejsze w $D R N$ jest zdecydowane odrzucenie idei, iż Żydzi są potępieni czy prze-

7 S. Krajewski jest publicystą żydowskim, współprzewodniczącym Polskiej Rady Chrześcijan i Żydów. 
klęci „rzekomo na podstawie Pisma Świętego”, potraktowanie religijności żydowskiej jako czegoś godnego szacunku (Krajewski, 2007, s. 78).

Adam Wąs ${ }^{8}$ dodaje, iż została założona Fundacja Nostra Aetate, a jej cel to promowanie dialogu oraz sponsorowanie wyznawcom innych religii studiów z zakresu chrześcijaństwa (Wąs, 2001, s. 89).

Ta deklaracja była owocem nowego porozumienia (Cassidy, 2005, s. 128). To symbol SWD, ewenement, który pomimo wielu znaków sprzeciwu, wyrasta z całej historii Soboru, zwłaszcza z rozeznania potrzeb oraz uwarunkowań czasu (Groblicki, Florkowski, 1986, s. 327). To pierwsze urzędowe zwrócenie się Kościoła do wszystkich religii niechrześcijańskich, co stanowi o jej nowości i oryginalności. Jej nowość widać również w jej warstwie motywacyjnej, którą jest zdanie Kościoła dotyczące „umacniania jedności i miłości między ludźmi oraz między narodami” (DRN, nr 1) (Ibidem, s. 329). Ponadto nowość stanowi wyraźnie postawione samo pytanie o religijne przewartościowanie chrześcijańskiej teologii judaizmu, islamu i innych religii, którego wcześniej unikano w oficjalnych rozważaniach, ponieważ wydawało się ryzykowne (Botkiewicz i in., 1999, s. 61-62).

Należy zauważyć, iż tragiczną wymowę ma fakt, iż bez Holocaustu nie powstałby prawdopodobnie ten dokument. Co prawda nie rozwiązał on wszystkich konfliktów nagromadzonych w dwutysięcznej historii, jednak otworzył możliwości, stwarzał zachętę do stawiania pytań, dyskusji (Wolff-Powęska, 2003, s. 391).

Deklaracja ta ,zawiera jasne wskazania, które inspirują Kościół do prowadzenia dialogu międzyreligijnego. Wskazania te obejmują głównie: szacunek względem własnego sumienia, odrzucenie wszelkich form nacisku i dyskryminacji religijnej, wolność wyznawania swojej wiary i dawania jej świadectwa oraz poszanowanie i uznanie dla wszystkich prawdziwych tradycji religijnych" (Sherwin, Kasimow, 2001, s. 220).

W niniejszym artykule autorka zaznaczyła, iż z powstaniem tego dokumentu wiązał się złożony proces obrad, w których społeczność żydowska odegrała bardzo ważną rolę. Zwróciła uwagę na zainteresowanie świata arabskiego tym dokumentem.

Przesłanie tego dokumentu jest następujące: wyznawcom różnych religii należy się szacunek, zwraca uwagę na konieczność prowadzenia dia-

8 A. Wąs jest religioznawcą, islamologiem, współprzewodniczącym Rady Wspólnej Katolików i Muzułmanów ze strony katolickiej. 
logu międzyreligijnego, działanie na rzecz wspólnego dobra, współpracę na rzecz sprawiedliwości, wolności i pokoju, miłość i solidarność między wyznawcami różnych religii, poszanowanie praw człowieka - prawa do godności ludzkiej, a zwłaszcza prawa do wolności religijnej, przeciwstawianie się wszelkim formom dyskryminacji, nienawiści, potępienie antysemityzmu. Ponadto wzywa do braterstwa między wyznawcami różnych religii, obowiązku rachunku sumienia Kościoła katolickiego, przebaczenia, które jest niezbędnym warunkiem trwałego pokoju. To stanowi jednocześnie o politycznym wymiarze tego dokumentu.

Teolog Stanisława Grabska podkreśla, iż zrozumienie $D R N$ może stać się kamieniem milowym naszej drogi ku Nowej Ewangelizacji, ku zrozumieniu miłości Boga. Wyznawcy różnych religii powinni służyć pojednaniu oraz pokojowi pomiędzy narodami i religiami (Grabska, 1995, s. 11).

\section{Bibliografia}

Bagrowicz J. (2006), Nostra aetate - wyzwanie dla pedagogii chrześcijańskiej, „Collectanea Theologica", nr 2, s. 7-27.

Bardecki A. (1966), Kościót epoki dialogu, Kraków.

Bogacki H., Moys S. (red.) (1968), Kościót w świetle Soboru, Poznań.

Bortkiewicz P. i in. (1999), Kościót XX wieku. Rozmowy E. K. Czaczkowskiej, Katowice.

Cassidy E. I. (2005), Rediscovering Vatican II. Ecumenism and Interreligious Dialogue: Unitatis Redintegratio, Nostra Aetate, New York.

Chat E. (2005), Chrześcijaństwo a islam - polemika i dialog, Kielce.

Chrostowski W., Rubinkiewicz R. (1990), Żydzi i judaizm w dokumentach Kościoła i nauczaniu Jana Pawla II (1965-1989), Warszawa.

Chrostowski W. (red.) (1992), Żydzi i chrześcijanie w dialogu. Materiały z Międzynarodowego Kolokwium Teologicznego w Krakowie - Tyńcu 24-27 IV 1988, Warszawa.

Chrostowski W. (1998), Ja jestem Józef Brat wasz. Księga pamiq̨tkowa ku czci Arcybiskupa Henryka Józefa Muszyńskiego Metropolity Gnieźnieńskiego w 65 rocznicę urodzin, 1998.

Chrostowski W. (2005), Żydzi i judaizm w nauczaniu Jana Pawła II 1978-2005, Warszawa.

Czajkowski Z. (1966), Ostatnia sesja Vaticanum II, Warszawa.

Fitzgerald M. L. (2005), Szacunek do wartości religijnych, thum. M. Wiertlewska, „W Drodze”, nr 12, s. 34-45. 
Gioia F. (1999), The Catholic Church and Other Religions, w: The community of religions: voices and images of the Parliament of the World's Religions, red. W. Teasdale, G. F. Cairns, New York, s. 83-90.

Górzna S. (2008), Dialog Kościoła katolickiego z islamem wedtug Jana Pawła II, „Ateneum Kapłańskie”, z. 1, s. 57-66.

Górzna S. (2013), Dzieci Abrahama. Dialog Kościoła katolickiego z islamem i judaizmem w Polsce w okresie pontyfikatu Jana Pawła II, Słupsk.

Grabska S. (1995), Dialog zamiast wrogości, ,Tygodnik Powszechny”, nr 44, s. 11.

Griffiths B. (1985), Powrót do środka, tłum. T. A. Malanowski, Warszawa.

Groblicki J., Florkowski E. (red.) (1986), Sobór Watykański II. Konstytucje, dekrety, deklaracje. Tekst polski, Poznań 1986.

Grinberg D. (2001), Antysemityzm, w: Wielka Encyklopedia PWN, t. 2, red. J. Wojnowski, Warszawa.

Ignatowski G. (1999), Kościoły wobec przejawów antysemityzmu, Łódź.

Ignatowski G. (2007), Ojcowie Soboru Watykańskiego II wobec Nostra aetate, Katowice.

Imbach J. (1985), Wielkie tematy Soboru, tłum. M. Szafrańska-Brandt, Warszawa.

Jan Paweł II (1994), Przekroczyć próg nadziei. Jan Paweł II odpowiada na pytania Vittoria Messoriego, Lublin.

Jarmusiewicz A. (2005), Polscy Żydzi. Dziedzictwo i dialog, Kraków.

Konig F., Kremer J. (1992), Żyć wiarq dzisiaj. Chrześcijaństwo u progu III Tysiaclecia, tłum. R. Rubinkiewicz, Lublin.

Kowalski A. (1994), Wspólne korzenie. Dialog chrześcijańsko-żydowski, Kraków.

Krajewski S. (2007), Tajemnica Izraela a tajemnica Kościoła, Warszawa.

Larebiere B. (1999), Jan Pawet II. Wielcy ludzie XX wieku, thum. M. Dobosiewicz-Weltschek i in., Warszawa.

Latourelle R. (1999), II Sobór Watykański, tłum. J. Kalina-Lis, „Znak”, nr 5, s. $146-160$.

Michel T., Fitzgerald M. (red.) (1994), Recognize the Spiritual Bonds which Unite Us. 16 years of Christian - Muslim Dialogue, Vatican City.

Mysłek W., Nowaczyk M. (red.) (1985), Kościół współczesny. Dwadzieścia lat po Soborze Watykańskim II, Warszawa.

Oppenheim B. W. (2000), Kościót katolicki w Polsce a walka z antysemityzmem. Wymiana doświadczeń amerykańskich i polskich. Materiaty z konferencji w Centrum Kultury Żydowskiej, Kraków, 14 czerwca 2000 roku, Kraków.

Pawłowicz Z. (1986), Człowiek a religia. Materiały katechetyczne dla kapłanów, Gdańsk.

Pilarczyk K. (red.) (1997), Żydzi i judaizm we współczesnych badaniach polskich. Materiaty z Konferencji Kraków 21-23 XI 1995, Kraków. 
Ruppert H. S., Arinze F. (2004), Building bridges. Interreligious dialogue on the path to world peace, New York 2004.

Sakowicz E. (1988), Dialog Kościoła z religiami pozachrześcijańskimi w nauczaniu Jana Pawła II, „Homo Dei”, nr 1, s. 38-42.

Sakowicz E. (1998), Chrześcijaństwo wobec islamu, „Homo Dei”, nr 1, s. 45-49.

Sakowicz E. (2000), Dialog Kościoła z islamem wedtug dokumentów soborowych i posoborowych (1963-1999), Warszawa.

Sakowicz E. (2002), Abraham i jego wiara w świetle dokumentów Kościoła dotyczacych dialogu katolicko-muzułmańskiego, „Collectanea Theologica”, nr 2, s. $143-156$.

Sakowicz E. (2005), Religioznawstwo. Przewodnik tematyczny, Lublin.

Schmidt S. (1992), Augustin Bea: The Cardinal of Unity, New York.

Sherwin B. L. (1995), Duchowe dziedzictwo Żydów polskich, tłum. W. Chrostowski, Warszawa.

Sherwin B. L., Kasimow H. (1999), John Paul II and interreligious dialogue, New York.

Sherwin B. L., Kasimow H. (2001), Jan Pawet II i dialog międzyreligijny, tłum. A. Nowak, Kraków.

Skowron-Nalborczyk A., Grodź S. (2003), Islam i chrześcijaństwo. Historia, dialog, współczesność, „Collectanea Theologica”, nr 1, s. 184-197.

Teissier H. (1992), Chrześcijanin wobec islamu, tłum. M. Bajerowicz, „Collectanea Theologica", nr 2, s. 155-173.

Turowicz J. (1990), Kościół nie jest łodzia podwodnq. (Wybór publicystyki z lat 1964-1987), red. J. Hennelowa, Kraków.

Waldenfels H. (1987), Religie odpowiedzia na pytanie o sens istnienia człowieka, tłum. E. Perczak, Warszawa.

Wawrzyńska-Furman L. (2007), Czy Kościół rzymskokatolicki naucza pogardy wobec Żydów?, „Studia i Dokumenty Ekumeniczne”, nr 1/2, s. 139-151.

Wąs A. (2001), Dialog chrześcijaństwa z islamem, w: Islam w Europie Wschodniej. Historia i perspektywy dialogu. Materiały Konferencji Naukowej w Olsztynie, $w$ dniu 26 I 2001 r., red. W. Nowak, J. J. Pawlik, Olsztyn, s. 83-105.

Weksler-Waszkinel R. J. (2000), Żydzi i judaizm w jubileuszowym rachunku sumienia, „Forum Teologiczne”, t. 1, s. 317-327.

Wnuk J. (1966), Finale Soboru i Episkopat Polski, Warszawa.

Wojtyła K. (1972), U podstaw odnowy. Studium o realizacji Vaticanum II, Kraków.

Wolanin A. (1993), Dialog chrześcijaństwa z innymi religiami, Kraków.

Wolff-Powęska A. (2003), A bliźniego swego...Kościoły w Niemczech wobec „problemu żydowskiego", Poznań.

Zizola G. (2000), Pontifex politicus, „Forum”, nr 25, s. 8-9. 


\title{
The Political Response to the Declaration on the Relation of the Church to Non-Christian Religions Nostra Aetate
}

\begin{abstract}
Summary
The opening of the Catholic Church to dialogue with other religions has its source in the Second Vatican Council (1962-1965), which in many documents expressed the positive attitude of the Catholic Church to non-Christian religions. It was a special landmark event in the history of the Catholic Church. The author presents a conciliatory document, which proposes that the faithful of the Church should establish a dialogue with the followers of different religions to respect the values present in these religions.

The Declaration on the Relation of the Church to Non-Christian Religions Nostra Aetate began the process of the re-orientation of the Church towards the followers of different religions, among others Islam and Judaism, which are based on the belief in one God (monotheism). Particular attention should be paid to item 3 of this Declaration, which emphasizes that the Catholic Church has regard for the followers of Islam and item 4, which contains the formulation of the Jewish responsibility for deicide and raises the painful issue of anti-Semitism, but not for political reasons. Through the Declaration, a lot of Catholics have changed their approach towards the followers of other religions.

This document is a testimony confirming the special concern of the Church about establishing friendly relations with the followers of different religions, among others Islam and Judaism. The author is convinced that the document contributes to the peaceful coexistence of religions, which should work towards peace between nations.
\end{abstract}

Key words: the Second Vatican Council, Declaration on the Relation of the Church to Non-Christian Religions Nostra Aetate, interreligious dialogue, Islam, Judaism 
